\title{
Low frequency of antibodies anti-Neospora caninum in rodents in Fernando de Noronha Island, Brazil
}

\author{
DÉBORA C.V. DE LIMA ${ }^{1}$, RENATA P.B. DE MELO ${ }^{1}$, MULLER R. ANDRADE ${ }^{1}$, ADRIANNE \\ M. DE ALCÂNTARA ${ }^{1,2}$, FERNANDO JORGE R. MAGALHÃES ${ }^{3}$, JÉSSICA C.S. CARVALHO', \\ RENATO A. DA SILVA ${ }^{1}$, MATEUS M. DA COSTA ${ }^{4}$ and RINALDO A. MOTA ${ }^{1}$
}

\author{
${ }^{1}$ Laboratório de Doenças Infectocontagiosas dos Animais Domésticos, Departamento de Medicina Veterinária. Universidade \\ Federal Rural de Pernambuco/SEDE, Rua Dom Manuel de Medeiros, s/n, Dois Irmãos, 52171-900 Recife, PE, Brazil \\ ${ }^{2}$ Departamento de Doenças Parasitárias, Universidade Federal de Alagoas/UFAL, \\ Fazenda São Luiz, s/n, 57700-000 Viçosa, AL, Brazil \\ ${ }^{3}$ Unidade de Vigilância em Saúde, Distrito Estadual de Fernando de Noronha, BR 363, \\ s/n, Floresta Nova, 53990-000 Fernando de Noronha, PE, Brazil \\ ${ }^{4}$ Universidade Federal do Vale do São Francisco/UNIVASF, Av. José de Sá \\ Maniçoba, s/n, Centro, 56304-917 Petrolina, PE, Brazil \\ Manuscript received on May 3, 2019; accepted for publication on July 17, 2019
}

\begin{abstract}
How to cite: LIMA DCV, MELO RPB, ANDRADE MR, ALCÂNTARAAM, MAGALHÃES FJR, CARVALHO JCS, SILVA RA, COSTA MM AND MOTA RA. 2019. Low frequency of antibodies anti-Neospora caninum in rodents in Fernando de Noronha Island, Brazil. An Acad Bras Cienc 91: e20190439. DOI 10.1590/0001-3765201920190439.
\end{abstract}

\begin{abstract}
This study aimed to evaluate the frequency of Neospora caninum antibodies in rodents from the Island of Fernando de Noronha, Brazil, and to contribute to epidemiological data on neosporosis in this region. Blood samples were collected from 154 black-rats (Rattus rattus) and 12 rock-cavies (Kerodon rupestris). The search for anti-N. caninum antibodies was made using the NAT technique, with a cut-off of 1:20. The frequency of positive mice was 5.19\% (8/154 - 1:20 titer) and all rock-cavies were negative. The low frequency of antibodies against $N$. caninum in rodents found in the Island shows the low contamination of the environment where these animals live.
\end{abstract}

Key words: Neosporosis, wildlife animals, NAT, Rattus rattus, Kerodon rupestris.

Neospora caninum is an intracellular, cyst-forming parasite responsible for the disease known as neosporosis, which causes reproductive and neurological conditions mainly in cattle and dogs, being the latter and other canids species considered as definitive hosts (Dubey et al. 2007). Small rodents like Mus musculus, Rattus norvergicus and Apodemus sylvaticus had already being confirmed as intermediate hosts to $N$. caninum (Ferroglio et

Correspondence to: Débora Costa Viegas de Lima

E-mail: deboracvlima@gmail.com

ORCid: https://orcid.org/0000-0002-7848-8769 al. 2007, Dubey and Schares 2011). In this sense, this research aimed to evaluate the frequency of antibodies to this pathogen in rodents from the Island of Fernando de Noronha, Brazil and contribute with epidemiological data on neosporosis in this insular environment.

The research was carried out on the Island of Fernando de Noronha, located in the Fernando de Noronha Archipelago ( $3^{\circ} 50^{\prime} 25 \mathrm{~S}, 32^{\circ} 24 ’ 38$ W), State of Pernambuco, Northeast Brazil. This project was approved by the Ethics Committee for the Use of Animals (CEUA (License 101/2015) and 
the System of Authorization and Information on Biodiversity - SISBIO (License 49198-1).

Rodents' capture was made using Tomahawk traps containing baits, being 154 black-rats (Rattus rattus) and 12 rock-cavies (Kerodon rupestris) captured. After physical restraint, the animals were sedated using a combination of Ketamine Hydrochloride (20mg kg/IM - Rock-cavies, 40mg/ $\mathrm{kg} / \mathrm{IM}$ - Rats) with Xylazine Hydrochloride (2mg/ $\mathrm{kg} / \mathrm{IM}$ - Rats and rock-cavies). After sedation, blood samples were collected by cardiac puncture in collecting tubes without anticoagulant. The samples were centrifuged at $1.500 \mathrm{rpm}$ for $8 \mathrm{~min}$. to obtain the serum and this was stored in an Eppendorf tube and stored at $-20{ }^{\circ} \mathrm{C}$ until processing.

To detect antibodies anti- $N$. caninum, the technique of Neospora agglutination test (NAT) was used, following protocol described by Lima et al. (2018) where the sera were diluted in PBS and placed on microplates at an initial cut-off of 1:20 and treated with 2-Mercaptoethanol (2-Me) solution. Subsequently the antigen $(N$. caninum tachyzoites at a concentration of $5 \times 10^{7} \mathrm{taqs} / \mathrm{ml}$ ) was added and then the samples were incubated at $30{ }^{\circ} \mathrm{C}$ overnight. The presence of a button-shaped deposit at the bottom of the well was interpreted as a negative reaction, while the formation of a complete carpet (antigens and agglutinated antibodies) was considered positive. Positive samples were titrated from 1:20 to 1:400. For this technique, positive and negative sera controls for both species (Rats and rock-cavies) were used.

The results of the serological examination (NAT) for N. caninum and the titrations found are presented in Table I.

This is the first report of the presence of anti-N. caninum antibodies in Rattus rattus on the Island of Fernando de Noronha, being one of the few studies of this issue in this and other species of rodents in the world. Urban and wild rodents are considered important intermediate hosts to the maintenance of $N$. caninum cycle, since they can
TABLE I

Result of serology analyses for detection of antibodies anti- $N$. caninum and titration in $R$. rattus and $K$. rupestris in the Island of Fernando de Noronha, Brazil.

\begin{tabular}{cccc}
\hline Species & Total & Positives (\%) & Titration \\
\hline Rattus rattus & 154 & $8(5,19 \%)$ & 20 \\
Kerodon rupestris & 12 & $0(0 \%)$ & - \\
\hline
\end{tabular}

be commonly predated by canids or accidentally by other animals, including farm animals, leading to cases of the disease (Meerburg et al. 2012).

Serological results indicate a low frequency of antibodies $(5.19 \%)$ against $N$. caninum in rodents. In order for the infection to occur in rodents, the ingestion of oocysts present in the soil is necessary (Meerburg et al. 2012), demonstrating the importance of the definitive hosts' presence for the transmission and maintenance of $N$. caninum in this environment. On the Island of Fernando de Noronha the presence of dogs is limited to urban areas and there is no contact of these animals with refugee species in the forests, such as rats and rockcavies, which may explain the low frequency of antibodies to $N$. caninum detected in this study, corroborating with the findings reported by Lima et al. (2018) in wild cats (Felis catus) on the Island.

NAT is a technique successfully used for the detection of $N$. caninum infection (experimental and natural) in different species, being of high sensitivity when compared to others indicated as reference tests as IFAT, but with no need of using specific conjugates for the species studied (Romand et al. 1998), being an advantage in the detection of IgG antibodies in researches of wild animals populations.

On the Island of Fernando de Noronha, a few serological survey studies were carried out for $N$. caninum, including in farm animals species. Lima-Filho (2015) detected the presence of anti- $N$. caninum antibodies in 84 (68.85\%) bovines on the Island, describing the presence of dogs in the properties as a risk factor for the high prevalence found. Lima et al. (2018) reported a 
low frequency of these antibodies in felines (Felis catus) $(3.11 \%-8 / 257)$, suggesting the absence of dogs in the locations where these cats inhabit as a point of fundamental importance for the lack of dissemination of $N$. caninum on the Island. These authors further suggest that the low frequency reported in these felines indicates low infection in the animals that are commonly predated by these animals such as the rodents of the Island.

The Fernando de Noronha archipelago is composed by islands, islets and cliffs of volcanic origin, presenting several hills and peaks where a wide diversity of vegetation is found (Almeida 2002), as well as native and invasivy animals. Rodents (black-rats and rock-cavies) are found on the Island of Fernando de Noronha in these places, which may hamper the access of definite hosts and the dispersion of oocysts in these localities.

In wild rodents, the presence of $N$. caninum was already reported by some authors such as Huang et al. (2004) in China and by Jenkins et al. (2007) in India in Rattus norvegicus and Mus musculus; by Ferroglio et al. (2012) in M. musculus, $R$. norvegicus and Apodemus sylvaticus from Italy; by Meerburg et al. (2012) in six different rodent species from Netherlands (M. musculus, Microtus arvalis, A. sylvaticus, Micromys minitus, Sorex araneus and Crocidura russula), suggesting that the transmission of this coccidia to these animals occurs through the ingestion of oocysts present in the soil; and by Dhandapani et al. (2017) in $R$. rattus from India, being the detection of this agent through molecular techniques that evidence the presence of the parasite in all the cited researches.

In Brazil, there are few studies that report the importance of synanthropic and wildlife rodents in the epidemiology of neosporosis, with most studies involving capybara (Hydrochaeris hydrochaeris) (Yai et al. 2008, Truppel et al. 2010, Valadas et al. 2010). In the state of São Paulo a study was conducted for the detection of antibodies against $N$. caninum in urban rats, with $0 \%$ of positivity in
$R$. rattus, $R$. norvegicus and M. musculus as these animals were from a place where dogs were absent (Muradian et al. 2012).

The low frequency of antibodies found in this study may also be related to the living habits of these rodent species. The rock-cavy and the black-rat are species commonly found in the forests and rocky regions of the Island where there is no presence of dogs. In addition, the rock-cavy presents a diet based on leafy foods (leaves, buds, flowers and tree barks) (Carvalho 1969), where there is usually no oocyst of $N$. caninum, which may justify the absence of $N$. caninum antibodies in this species, although the low numbers of captured animals also influence this result. Rats are considered omnivorous and highly adaptive in insular environment and their diet is based on diverse vegetation (leaves, flowers, stems, woods), fruits, small vertebrates and invertebrates and grains present in the soil (Riofrío-Lazo and Páez- Rosas, 2015) that may be contaminated with oocysts, which may explain the presence of antibodies, in addition to the fact that these animals are closer to the urban areas where dogs are present.

The low frequency of antibodies against $N$. caninum in black rats on the Island of Fernando de Noronha demonstrates the low contamination and dispersion of oocysts of this agent in the environment inhabited by these animals.

\section{ACKNOWLEDGMENTS}

The authors would like to thank the Fundação de Amparo a Ciência e Tecnologia de Pernambuco (FACEPE) and the Coordenação de Aperfeiçoamento de Pessoal de Nível Superior (CAPES) for the financial support. None of the authors declares any conflict of interest.

\section{AUTHOR CONTRIBUTIONS}

Lima D, Costa M and Mota R contributed to the project design and implementation of the research, 
to the analysis of the results and to the writing of the manuscript. Lima D, Alcântara A and Andrade $\mathrm{M}$ assisted with sample collection. Magalhães $\mathrm{F}$ organized all stages of visits and sample collection on the island. Carvalho J and Silva R assisted in the serological analysis steps.

\section{REFERENCES}

ALMEIDA FFM. 2002. Arquipélago de Fernando de Noronha - Registro de monte vulcânico do Atlântico Sul. In: Schobbenhaus C et al. (Eds), Sítios Geológicos e Paleontológicos do Brasil. DNPM/CPRM - Comissão Brasileira de Sítios Geológicos e Paleobiológicos (SIGEP), Brasília, 554 p.

CARVALHO JCM. 1969. Notas da viagem de um zoólogo à região das caatingas e áreas limítrofes. Imprensa Universitária do Ceará, Ceará, p. 134-135.

DHANDAPANI K, SREEKUMAR C, SANGARAN AND PORTEEN K. 2017. Investigations into the role of rats as intermediate hosts for Neospora caninum in Chennai, India. Vet Parasitol Reg Studies Reports 7: 36-39.

DUBEY JP AND SCHARES G. 2011. Neosporosis in animalsthe last five years. Vet Parasitol 180(1-2): 90-108.

DUBEY J, SCHARES G AND ORTEGA-MORA LM. 2007. Epidemiology and control of neosporosis and Neospora caninum. Clin Microbiol Rev 20(2): 323-367.

FERROGLIO E, PASINO M, ROMANO A, GRANDE D, PREGEL P AND TRISCIUOGLIO A. 2007. Evidence of Neospora caninum DNA in wild rodents. Vet Parasitol 148: 346-349.

LIMA DCV, MAGALHÃES FJR, ANDRADE MR, SILVA JGD, MORAIS EGF, LIMA-FILHO CDF, PORTO WJN AND MOTARA. 2018. Anti-Neospora caninum antibodies in feral cats on the Island of Fernando de Noronha, Brazil. Acta Parasitol 63(3): 645-646.

LIMA-FILHO CDF. 2015. Prevalência e fatores de risco associados à infecção por Neospora caninum (Dubey, Carpenter, Speer, Topper e Uggla, 1988) em bovinos no Arquipélago de Fernando de Noronha, Pernambuco,
Brasil (Master thesis), Universidade Federal Rural de Pernambuco), 46 p. (Unpublished).

HUANG CC, YANG CH, WATANABE Y, LIAO YK AND OOI HK. 2004. Finding of Neospora caninum in the wild brown rat (Rattus norvegicus). Vet Res 35: 283-290.

JENKINS MC, PARKER C, HILL D, PINCKNEY RD, DYER R AND DUBEY JP. 2007. Neospora caninum detected in feral rodents. Vet Parasitol 143(2): 161-165.

MEERBURG BG, DE CRAEYE S, DIERICK K AND KIJLSTRA A. 2012. Neospora caninum and Toxoplasma gondii in brain tissue of feral rodents and insectivores caught on farms in the Netherlands. Vet Parasitol 184(24): $317-320$.

MURADIAN V, FERREIRA LR, LOPES EG, ESMERINI PDE, PENA HF, SOARES RM AND GENNARI SM. 2012. A survey of Neospora caninum and Toxoplasma gondii infection in urban rodents from Brazil. J Parasitol 98(1): 128-134.

RIOFRÍO-LAZO M AND PÁEZ-ROSAS D. 2015. Feeding Habits of Introduced Black Rats, Rattus rattus, in Nesting Colonies of Galapagos Petrel on San Cristóbal Island, Galapagos, PLoS ONE 10(5): 1-14.

ROMAND S, THULLIEZ P AND DUBEY JP. 1998. Direct agglutination test for serologic diagnosis of Neospora caninum infection. Parasitol Res 84: 50-53.

TRUPPEL JH, MONTIANI-FERREIRA F, LANGE RR, VILANI RG, REIFUR L, BOERGER W, DA COSTARIBEIRO MC AND THOMAZ-SOCCOL V. 2010. Detection of Neospora caninum DNA in capybaras and phylogenetic analysis. Parasitol Int 59: 376-379.

VALADAS S, GENNARI SM, YAI LE, ROSYPAL AC AND LINDSAY DS. 2010. Prevalence of antibodies to Trypanosoma cruzi, Leishmania infantum, Encephalitozoon cuniculi, Sarcocystis neurona, and Neospora caninum in capybara, Hydrochoerus hydrochaeris, from São Paulo State, Brazil. J Parasitol 96: 521-524.

YAI LE, RAGOZO AM, CAÑÓN-FRANCO WA, DUBEY JP AND GENNARI SM. 2008. Occurrence of Neospora caninum antibodies in capybaras (Hydrochaeris hydrochaeris) from São Paulo state, Brazil. J Parasitol 94: 766. 